\title{
Evaluation of kimberlite diamond potential using FTIR spectroscopy of xenocrystic olivine
}

\author{
Sergei Matveev ${ }^{1}$ and Thomas Stachel ${ }^{1}$ \\ ${ }^{1}$ Department of Earth and Atmospheric Sciences, University of Alberta, Edmonton, Canada
}

\section{Introduction}

A significant proportion of macro-crystalline material within kimberlite is xenocrystic, representing disintegrated peridotite from potentially diamondbearing mantle. Xenocrysts are not in chemical equilibrium with the transporting magma and thus often are being altered or dissolved in the course of ascent. Identifying preserved mantle xenocrysts in disequilibrium with the host magma and determining the factors that assisted their fast ascent to the Earth's surface may help to predict both the diamond grade of a kimberlite and the degree of diamond preservation.

To evaluate the degree of preservation of peridotitic material in kimberlitic magma we studied FTIR spectra of olivine xenocrysts. Visually, peridotitic olivine in kimberlite often appears unmodified. FTIR spectroscopy, however, shows that the olivine crystal structure is commonly affected by the hydrous kimberlitic magma. At high pressure and temperature interaction with a hydrous magma causes formation of new cation vacancies in olivine which are chargecompensated by protons. Hydrogenation of the olivine structure is a relatively fast process with kinetics that are well constrained experimentally (hours to a few days for the hydrogenation of millimeter sized crystals; Demouchy and Mackwell, 2006). As a result of magma-olivine interaction at depth, many xenocrystic kimberlitic olivines acquire a strong and homogeneous $\mathrm{OH}$ IR signal. Due to the very fast ascent rate of kimberlitic magma this signal is generally preserved in olivines found at surface (Matveev and Stachel, 2007; Peslier et al., 2008). At the same time, some olivines are protected from direct contact with the kimberlitic magma by being included in diamonds or in the core of mantle xenoliths. In this paper, spectroscopic characteristics of the latter group of olivines are used to establish criteria for the identification of peridotitic material in kimberlites that largely escaped modification. In addition, FTIR spectroscopy of individual olivine grains from different kimberlites are studied to identify additional spectroscopic features which may correspond to diamond grade and/or degree of diamond preservation.

\section{Analytical procedure}

All studied olivines, with the exception of inclusions in diamonds, were polished from both sides prior to analysis to produce $\sim 300$ micron thick platelets. Due to their small size, olivine inclusions in diamonds were analyzed without being polished. FTIR spectra were acquired in transmitting mode with a Continuum IR microscope attached to Nexus 470 FTIR spectrometer. Details of the analytical procedure, setup and spectra classification used here are given in Matveev and Stachel (2007).

\section{Olivine inclusions in diamonds}

We have studied 14 olivine inclusions in diamonds from Birim field (Akwatia, Ghana; Stachel and Harris, 1997) and two olivine inclusions in diamonds from the A154-S kimberlite (Diavik, Canada; Donnelly et al., 2007). Olivine inclusions from both localities were spectroscopically anhydrous $\left(<1 \mathrm{ppm} \mathrm{H}_{2} \mathrm{O}\right.$; Fig. 1, bottom). We assume that these olivines were anhydrous during entrapment and subsequently preserved this feature during transport to the surface within a hydrous kimberlitic magma due to the shielding effect of their diamond hosts. Spectroscopically dry inclusions in diamonds imply a generally anhydrous nature of subcratonic lithospheric mantle and also suggest formation of gem diamonds at anhydrous conditions. Hydrogenation of peridotitic olivine from kimberlites, therefore, occurs during interaction of primarily anhydrous peridotitic olivines with hydrous kimberlitic melt.

\section{Olivines from diamond-bearing peridotitic xenoliths}

The hydroxyl content in olivines from four diamondiferous peridotite xenoliths from the Finsch kimberlite (South Africa) was found to be relatively low ( $<40 \mathrm{ppm} \mathrm{H}_{2} \mathrm{O}$; Fig 1, middle). One of the characteristic features of FTIR spectra of olivines from diamond-bearing peridotite xenoliths is the presence of Group 2 bands $\left(3355-3328 \mathrm{~cm}^{-1}\right)$ indicative of equilibration with orthopyroxene (Matveev et al., 2001). With increasing water content (20 - $40 \mathrm{ppm}$ $\mathrm{H}_{2} \mathrm{O}$ ) the intensity of higher frequency bands (3500 $3650 \mathrm{~cm}^{-1}$ ) increases, which may reflect beginning 
equilibration with a hydrous, $\mathrm{SiO}_{2}$-undersaturated, kimberlitic melt. In this case, the somewhat elevated water contents in olivines from diamond-bearing xenoliths, relative to inclusions in diamond, would imply that xenolithic material is not completely preserved from interaction with hydrous kimberliterelated melt (or other hydrous metasomatic agent). Nevertheless, low water concentrations in xenocrystic olivines associated with diamond suggest that this feature can be used to evaluate the proportion of well preserved peridotitic material within a kimberlite pipe, down to the level of individual pyroclastic or intrusive units.

\section{Olivines from economic kimberlites}

Olivine macrocrysts from high grade kimberlites show the entire range of FTIR spectra and $\mathrm{OH}$ concentrations typical for kimberlitic olivines in general, including water-poor grains characterized by presence of both Group $1 A$ bands and relatively strong Group 2 bands (Fig 1, upper section). This implies the preservation of xenocrystic material, including diamond.

Somewhat unexpectedly, olivines from Lac de Gras kimberlites with the lowest degree of diamond resorption (Panda and Beartooth, NWT, Canada; Fedorchuk and Canil, 2005) show very strong IR OH absorption associated with Group $1 B$ bands corresponding to $>400 \mathrm{ppm}$ of $\mathrm{H}_{2} \mathrm{O}$. Comparison with water concentrations in experimentally annealed olivines (Kohlstedt et al., 1996; Matveev et al., 2001) suggests that water rich olivines with Group $1 B$ bands equilibrated with a hydrous fluid at $1.5-2 \mathrm{GPa}$. This apparent paradox - high water concentrations in olivine associated with well preserved diamonds - may relate to hydrofracturing during fluid exsolution which assist rapid ascent of the kimberlitic magma through the rheological barrier associated with the Moho discontinuity. Although such exsolved hydrous fluids may dissolve diamonds, the transport channels for rapid ascent generated as a result of fluid exsolution may more than over-compensate increased dissolution by assuring better diamond preservation in subsequent magma batches. Samples from the Victor kimberlite (Ontario, Canada) confirmed that a combination of water-poor $(<100 \mathrm{ppm})$ olivines with high pressure Group $1 \mathrm{~A}$ bands and water-rich (>300 ppm) olivines with lower pressure Group $B$ bands is associated with higher grade sections of kimberlite.

Group 2 bands were not observed in olivines from low grade kimberlites containing graphitized diamonds (Grizzly and Leslie, NWT, Canada). Such diamonds did not show surface features associates with the effect of a fluid (Fedortchouk et al., 2005; Fedortchouk et al., abstract IKC9 00279). Perhaps presence of fluid phase is required to stabilize crystal point defects associated with Group 2 bands. This would be in line with previous experimental results (Matveev et al., 2001 and

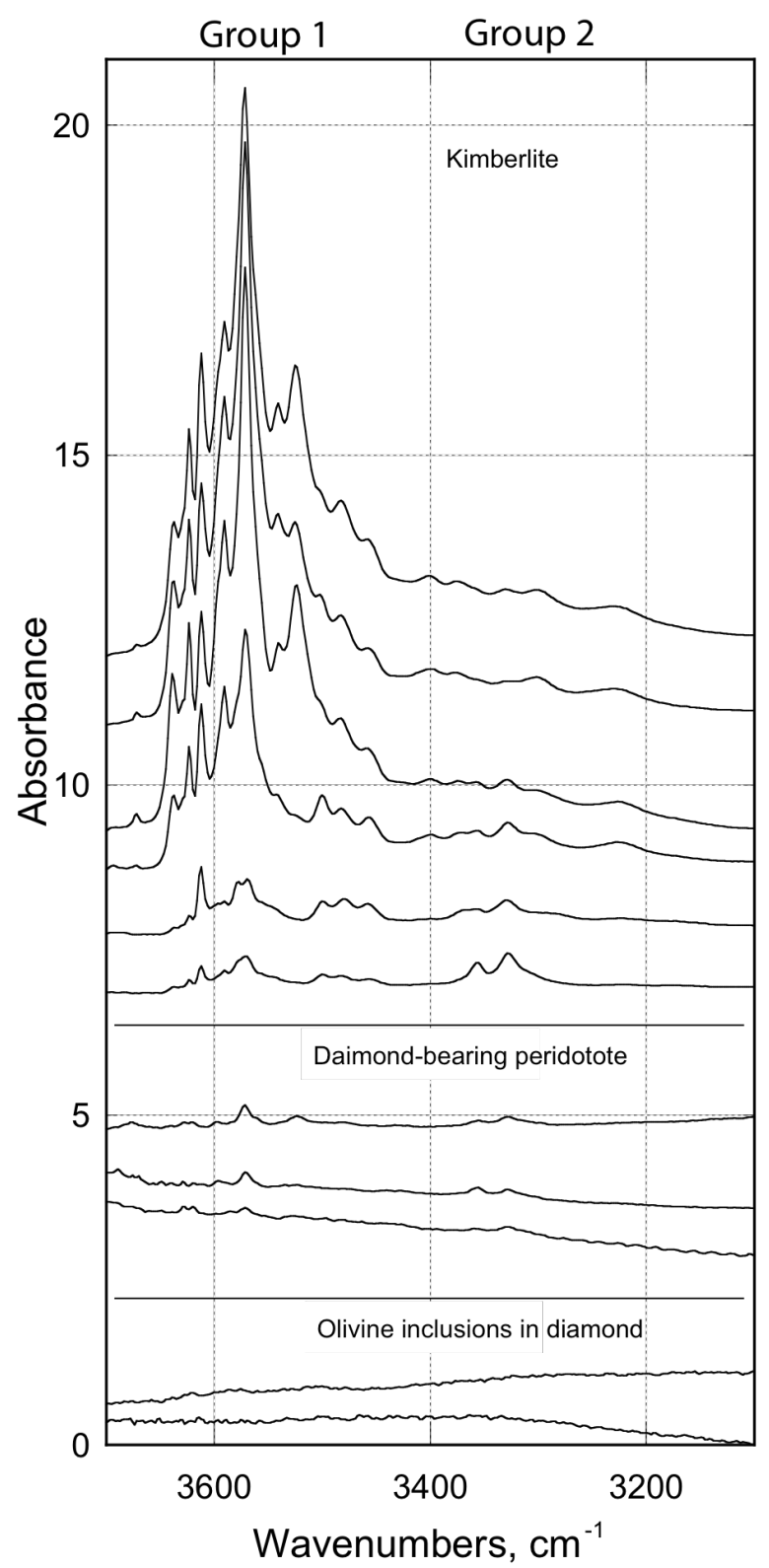

Fig. 1 Representative spectra of studied olivines. Absorbances are normalized to $1 \mathrm{~cm}$ sample thickness. Beam orientation is parallel to [010]. Spectra are stacked for clarity.

refs. therein). If this proposition is correct Group 2 bands could be used to detect fluid exsolution and used as an additional indicator of diamond preservation.

The utilization of infrared spectra of kimberlite hosted olivines as predictive tool for diamond grade needs to be further evaluated through the study of kimberlite samples with variable diamond grades so that a sound statistical basis can be established. 


\section{Conclusions}

Originally, peridotitic material in the lithospheric mantle probably is anhydrous. Hydrogenation of xenocrystic olivine then occurs as a result of the interaction with hydrous kimberlitic melts. The presence of water-poor olivine xenocrysts with Group $1 A$ and Group $2 \mathrm{OH}$ IR absorption bands is indicative of the preservation of xenocrystic material, including diamonds. Strong Group $1 B \mathrm{OH}$ IR bands are indicative of fluid exsolution near the depth of the Moho. High grade kimberlites appear to be characterized by olivines showing a combination of low intensity Group $1 A$ bands and strong Group $1 B$ bands.

\section{References}

Demouchy, S. and Mackwell, S., 2006. Mechanisms of hydrogen incorporation and diffusion in ironbearing olivine. Physics and Chemistry of Minerals 33, 347-355

Donnelly, C. L., Stachel, T., Creighton, S., Muehlenbachs, K., and Whiteford, S., 2007. Diamonds and their mineral inclusions from the A154 South pipe, Diavik Diamond Mine, Northwest territories, Canada. Lithos 98, 160-176.

Fedortchouk, Y., Canil, D., and Carlson, J., 2005. Dissolution forms in Lac de Gras diamonds and their relationship to the temperature and redox state of kimberlite magma. Contribution to Mineralogy and Petrology 150, 54-69.

Kohlstedt, D. L., Keppler, H., and Rubie, D. C., 1996. Solubility of water in the alpha, beta and gamma phases of $(\mathrm{Mg}, \mathrm{Fe})_{2} \mathrm{SiO}_{4}$. Contribution to Mineralogy and Petrology 123, 345-357.

Matveev, S., O'Neill, H. S. C., Ballhaus, C., Taylor, W. R., and Green, D. H., 2001. Effect of silica activity on OH- IR Spectra of olivine: Implications for lowaSiO2 mantle metasomatism. Journal of Petrology 42, 721-729.

Matveev, S. and Stachel, T., 2007. FTIR spectroscopy of OH in olivine: A new tool in kimberlite exploration. Geochimica et Cosmochimica Acta 71, 5528-5543.

Peslier, A. H., Woodland, A. B., and Wolff, J. A., 2008. Fast kimberlite ascent rates estimated from hydrogen diffusion profiles in xenolithic mantle olivines from southern Africa. Geochimica et Cosmochimica Acta 72, 2711-2722.

Stachel, T. and Harris, J. W., 1997. Syngenetic inclusions in diamond from the Birim field (Ghana) - a deep peridotitic profile with a history of depletion and re-enrichment. Contribution to Mineralogy and Petrology 127, 336-352. 